\title{
GROWTH AND MINERAL NUTRITION OF Solanum americanum ${ }^{1}$
}

\author{
Crescimento e Nutrição Mineral de Solanum americanum
}

\author{
BIANCO, S. ${ }^{2}$, CARVALHO, L.B. ${ }^{3}$ and BIANCO, M.S. ${ }^{4}$
}

\begin{abstract}
A greenhouse trial was carried out from November 1995 to April 1996 at FCAV/ UNESP, Brazil, aiming to study the dry matter production and the accumulation and distribution of macronutrients in Solanum americanum, an important weed for annual and perennial crops in Brazil. The plants were grown in seven liter pots with sand substrate, irrigated daily with Hoagland \& Arnon nutrient solution. The experimental design was completely randomized with four replicates. The treatments corresponded to evaluation times at 14 day intervals, beginning 21 days after emergence (DAE). In each evaluation, the plants of four pots were analyzed for dry matter production and macronutrient content. S. americanum had a small dry matter and macronutrient accumulation at the beginning of the experimental stage, increasing after $77 \mathrm{DAE}$ and reaching the maximum theoretical value at $142,142,164$, 149, 140, 149 and 152 DAE, for dry matter, N, P, K, Ca, Mg, and S, respectively. K and N were the most accumulated macronutrients for $S$. americanum plants.
\end{abstract}

Keywords: weed, American black nightshade, dry matter, macronutrients.

RESUMO - Um experimento em casa de vegetação foi conduzido entre novembro de 1995 e abril de 1996 na FCAV/ UNESP, Brasil, objetivando estudar a produção de matéria seca, a distribuição e o acúmulo de macronutrientes por Solanum americanum - uma importante planta infestante de culturas anuais e perenes no Brasil. As plantas foram cultivadas em vasos de $7 \mathrm{~L}$ com substrato de areia, os quais foram irrigados diariamente com solução nutritiva de Hoagland \& Arnon. O delineamento experimental foi inteiramente casualizado, com quatro repetições. Os tratamentos corresponderam às épocas de avaliação, em intervalos de 14 dias, iniciando-se 21 dias após a emergência (DAE). Em cada avaliação, as plantas de quatro vasos foram analisadas quanto à produção de matéria seca e ao conteúdo de macronutrientes. S. americanum apresentou pequeno acúmulo de matéria seca e de macronutrientes no início da fase experimental. Esses acúmulos intensificaram-se após 77 DAE, atingindo o máximo valorteórico aos 142, 142, 164, 149, 140, 149 e 152 DAE, para matéria seca, $N$, $P, K, C a, M g$ e $S$, respectivamente. K e $N$ foram os macronutrientes acumulados em maior quantidade porplantas de $S$. americanum.

Palavras-chave: plantas daninhas, maria-pretinha, matéria seca, macronutrientes.

\section{INTRODUCTION}

Solanum americanum, firstly described by Philip Miller in 1768, is an indigenous plant from North America (Manoko et al., 2007), which is widely distributed in agricultural lands in Brazil and worldwide (Kissmann \& Groth, 1999; Lorenzi, 2000). In the last years, the species has been reported infesting horticulture and field crops such as cotton (Corrêa \& Sharma, 2004), papaya (Ronchi et al., 2008), onion (Soares et al., 2003, 2004),

Recebido para publicação em 21.8.2009 e na forma revisada em 15.6.2010.

2 Prof. Livre Docente do Dep. de Biologia Aplicada à Agropecuária, Faculdade de Ciências Agrárias e Veterinárias, Universidade Estadual Paulista, FCAV/UNESP, Via de Acesso Prof. Paulo Donato Castellane s/n, 14884-900 Jaboticabal-SP, <sbianco@fcav.unesp.br>; ${ }^{3}$ Doutorando do Programa de Pós-Graduação em Produção Vegetal, FCAV/UNESP, Jaboticabal-SP, bolsista do CNPq, <agrolbcarvalho@gmail.com>; ${ }^{4}$ Mestrando do Programa de Pós-Graduação em Produção Vegetal, FCAV/UNESP, Jaboticabal-SP, bolsista do CNPq, <matbianco2004@yahoo.com.br>. 
peanut (Nepomuceno et al., 2007a; Dias et al., 2009), potato (Blanco, 2008), red beet (Carvalho et al., 2008a,b; Carvalho \& Guzzo, 2008), soybean (Nepomuceno et al., 2007b), sugar cane (Kuva et al., 2007; Monquero et al., 2008), tomato (Nascente et al., 2004; Hernandez et al., 2007) and watermelon (Adkins et al., 2008; Gilbert et al., 2008).

In general, weeds have a specific characteristic that allows their ecophysiological adjustment in different environments, known as phenotypic plasticity; at each environment, weed populations may suffer evolving genetic modifications that may be extended to subsequent generations (Pitelli \& Pavani, 2004). For these reasons, weed populations may show different responses to distinct methods of management. Thus, basic studies on the biology of weeds are essential to understand the behavior of weeds growing under different environmental conditions (Bianco et al., 2004a, b) as a support to weed management. Considering the importance of $S$. americanum as weed, basic studies are necessary concerning the biology of this species, regarding some aspects such as reproduction, growth, development and mineral nutrition, as well as management systems. These studies are important to obtain substantial information to help manage this weed.

Information on the nutritional requirements of weeds is important to weed science, since nutrient competition is one of the main ecological factors that affect negatively crop productivity (Andreasen et al., 2006; Olykan et al., 2008). Due to this fact, important studies have already been conducted for Senna obtusifolia (Erasmo et al., 2000), Urena lobata (Souza Filho et al., 2000), Cardiospermum halicacabum (Brighenti et al., 2003), Richardia brasiliensis competing with Glycine max (Pedrinho Júnior et al., 2004), Quercus petraea, Fagus sylvatica, Acer pseudoplatanus (Kazda et al. 2004), Brachiaria decumbens (Bianco et al., 2005), Euphorbia heterophylla competing with G. max (Bianco et al., 2007), Brachiaria plantaginea competing with Zea mays (Carvalho et al., 2007), Ipomoea nil (Duarte et al., 2008) and Ipomoea quamoclit (Carvalho et al., 2009).
No information is available in the literature on growth and mineral nutrition of $S$. americanum. However, efforts must be done to study the biology of this important weed in Brazil. So, the objective of this research was to study the dry matter production and macronutrients distribution and accumulation in S. americanum plants, growing under standard nutrient conditions.

\section{MATERIALS AND METHODS}

A greenhouse trial was carried out at Faculdade de Ciências Agrárias e Veterinárias (FCAV) of São Paulo State University (UNESP), Jaboticabal-SP, Brazil. The experiment was conducted from November 1995 to April 1996, using seven liter plastic pots and river sand as substrate.

Twenty seeds of $S$. americanum were sown in November 1995. After four leaves were attained, only four S. americanum plants per plot were maintained until the end of the experimental stage. The pots were irrigated three times a day with the nutrient solution of Hoagland \& Arnon (1950), supplying equal amounts of $100 \mathrm{~mL}$ at $10 \mathrm{am}, 1 \mathrm{pm}$ and $4 \mathrm{pm}$. At 35 days after emergence (DAE), the irrigation was performed at a concentration of $25 \%$ of this solution; after 35 DAE until the end of the experimental stage, at a concentration of $50 \%$. These concentrations were obtained mixing the original solution with deionized water in proportion of $1: 3(25 \%)$ and $1: 1(50 \%)$.

The experimental design was completely randomized with four replicates. Treatments were determined by proper evaluation times at $21,35,49,63,77,91,105,119,133,147$ and $161 \mathrm{DAE}$. At each time, plants from the four pots were analyzed, considering each pot as one replicate.

For the evaluations, S. americanum plants were collected and partitioned into roots, stems, leaves and reproductive structures (flowers and fruits). These materials were washed according to procedure described by Sarruge \& Haag (1974) and dried at $60-70{ }^{\circ} \mathrm{C}$ in a forced air convection oven for 96 hours.

Dried materials were weighted to determine the dry matter accumulation, sequentially powdered using a Willey mill 
grinder with 20-mesh steel screen and stored in glass pots with silicon lid. Ground samples were submitted to different extraction methods for nutrient rate determination in roots, stems, leaves, and reproductive structures. Nitrogen $(\mathrm{N})$ and phosphorus $(\mathrm{P})$ rates were attained according to the methodologies described by Sarruge \& Haag (1974). Potassium (K), calcium (Ca) and magnesium (Mg) rates were determined according to the methodologies described by Jorgensen (1977), while sulfur (S) rate was reached according to the methodology described by Vitti (1989).

Macronutrient accumulation in the roots, stems, leaves and reproductive structures was calculated by multiplying the nutrient rate in each structure and the correspondent dry matter accumulation. Total accumulation of each macronutrient was calculated by adding the accumulation of the nutrient in the roots, stems, leaves and reproductive structures. The total rate for each macronutrient was achieved in function of the relation between total nutrient accumulation and total dry matter accumulation.

Accumulation of dry matter and macronutrients was submitted to regression analysis in function of the theoretical exponential model $y=\exp \left(a+b x+c x^{2}\right)$ : where $y$ indicates dry matter or macronutrient accumulation and $\mathrm{x}$ represents days after emergence. So, points of maximum theoretical dry matter (PMtADM) and macronutrient (PMtAM) accumulation were calculated by the first derivative of the adjusted equation.

\section{RESULTS AND DISCUSSION}

Dry matter accumulation for S. americanum plants was slow at the beginning of the experimental stage (Figure 1A), but reached a theoretical value of $179.62 \mathrm{~g} \mathrm{plant}^{-1}$ at the PMtADM (142 DAE). After this period, there was a reduction of total dry matter accumulation due to plant senescence. Growing under same conditions, D. tortuosum, E. heterophylla, $H$. suaveolens, I. nil, I. quamoclit, R. brasiliensis and S. obtusifolia showed the most dry matter accumulation at 161, 116, 145, 123, 146, 147 and $147 \mathrm{DAE}$, as observed by Gravena et al., (2002), Bianco et al. (2004b), Pedrinho Júnior et al. (2004) Bianco et al. (2007), Duarte et al. (2008), Bianco et al. (2008) and Carvalho et al. (2009), Moreover, dry matter accumulation of these broadleaved weeds was less than that one of $S$. americanum, showing that $S$. americanum may grow more than these weeds.

In general, the broadleaved weeds already studied, such as $D$. tortuosum, E. heterophylla, H. suaveolens, I. nil, I. quamoclit, $R$. brasiliensis and S. obtusifolia, showed slow dry matter accumulation at the beginning of their life cycle, as verified by Gravena et al., (2002), Bianco et al. (2004b), Pedrinho Júnior et al. (2004) Bianco et al. (2007), Duarte et al. (2008), Bianco et al. (2008), and Carvalho et al. (2009), respectively. It is because plants demand a small amount of environmental resources, as water and nutrients, for initial growth, which increase greatly throughout the plant development (Taiz \& Zieger, 2002).

It was ascertained considerable dry matter accumulation from 63 to 119 DAE (Figure 1A). During this period, high dry matter increase occurred mainly as a function of accumulation in stems (Figure 1B). Moreover, by dividing the experimental stage into three parts, the percentage of accumulated dry matter in leaves was higher than in other structures in the first part, while stem percentage was greater than in other structures in the third part (Figure 1B).

The percentage of accumulated dry matter in roots increased from 21 to $49 \mathrm{DAE}$, decreasing from 49 to 105 and increasing afterwards (Figure 1B). This slight early increase may have allowed the plant to be able to fix itself on the substrate, increasing the contact with the nutrients, thereby leading to their quick uptake (Carvalho et al., 2007).

The percentage of dry matter accumulation in stems increased substantially after $21 \mathrm{DAE}$, decreasing mainly in leaves (Figure 1B). It provided greater percentage of dry matter accumulation in stems than other structures from 63 to $161 \mathrm{DAE}$.

Flowering of $S$. americanum occurred between 35 and $49 \mathrm{DAE}$. The percentage of accumulated dry matter in reproductive structures was small, but the highest value was $8.05 \%$ at 105 DAE (Figure 1B). 

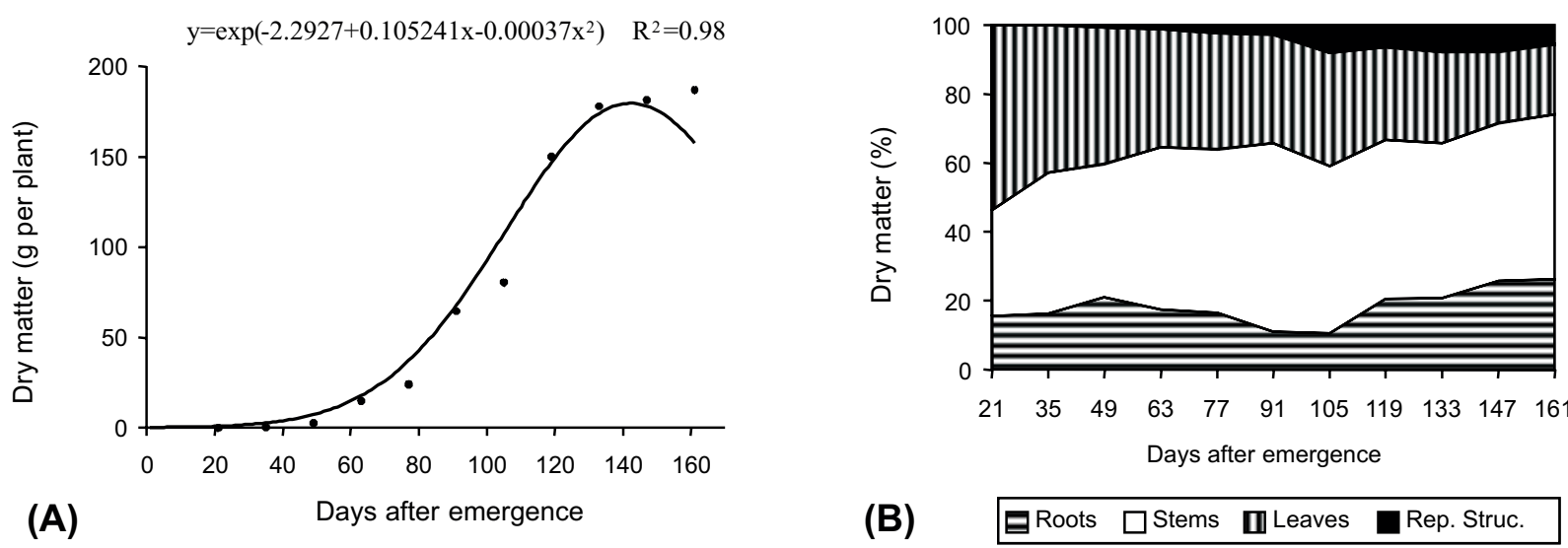

Figure 1 - Regression of dry matter accumulation data (A) and percentage of dry matter distribution (B) in Solanum americanum plants grown under standard nutrient conditions.

It is important to point out that there was intense decrease in the percentage of accumulated dry matter in leaves after flowering likely due to the change of the main site of nutrient absorption from the leaves to the reproductive structures. This fact had also been observed in studies with other weeds, according to reports of Bianco et al. (2004b) on Desmodium tortuosum, Bianco et al. (2004a) on Rottboellia exaltata, Pedrinho Júnior et al. (2004) on R. brasiliensis, Bianco et al. (2007) on E. heterophylla, Carvalho et al. (2007) on $B$. plantaginea, Duarte et al. (2008) on I. nil and Carvalho et al. (2009) on I. quamoclit.

The sequence of macronutrients with the highest rates in $S$. americanum plants was $\mathrm{K}$, $\mathrm{N}, \mathrm{Ca}, \mathrm{Mg}, \mathrm{P}$ and $\mathrm{S}$, respectively (Table 1). Macronutrients rates oscillated throughout the experimental stage. The highest rates of $\mathrm{N}, \mathrm{P}$ and $\mathrm{K}$ were observed at $21 \mathrm{DAE}$, whereas the $\mathrm{Ca}, \mathrm{Mg}$ and $\mathrm{S}$ highest rates were verified at 49, 91 and $147 \mathrm{DAE}$, respectively. When studying mineral nutrition in broadleaved weeds, Bianco et al. (2004b), Pedrinho Júnior et al. (2004), Bianco et al. (2007), Bianco et al. (2008), Duarte et al. (2008) and Carvalho et al. (2009) observed that $\mathrm{K}$ and $\mathrm{N}$ were the macronutrients presenting the highest rates in plants such as $D$. tortuosum, $R$. brasiliensis, E. heterophylla, S. obtusifolia, I. nil and I. quamoclit, respectively.

The accumulation of macronutrients in S. americanum plants was small at the beginning of the experimental stage (Figure 2), increasing after the first part of the total stage, reaching the PMtAM at $142 \mathrm{DAE}(5,461.94 \mathrm{mg}$ of $\mathrm{N}$ per plant), $164 \mathrm{DAE}$ (540.31 mg of $\mathrm{P}$ per plant), $149 \mathrm{DAE}(6,581.34 \mathrm{mg}$ of $\mathrm{K}$ per plant), $140 \mathrm{DAE}(3,751.46 \mathrm{mg}$ of Ca per plant), $149 \mathrm{DAE}$ (1,340.59 $\mathrm{mg}$ of $\mathrm{Mg}$ per plant) and $152 \mathrm{DAE}$ (612.73 $\mathrm{mg}$ of $\mathrm{S}$ per plant).

Large accumulations of $\mathrm{N}, \mathrm{K}$ and $\mathrm{Mg}$ were observed from 77 to 133 DAE (Figure 2A, 2C and $2 \mathrm{E}$ ). There were real accumulations of $4,888.84 \mathrm{mg}, 5,254.60 \mathrm{mg}$ and $1,044.48 \mathrm{mg}$ of $\mathrm{N}, \mathrm{K}$ and $\mathrm{Mg}$ per plant at $133 \mathrm{DAE}$, respectively. Nevertheless, a great accumulation of $P$ was verified from 77 to $147 \mathrm{DAE}$, while it was observed from 77 to $119 \mathrm{DAE}$ for Ca and from 91 to $133 \mathrm{DAE}$ for S (Figures 2B, 2D and 2F). There was a real accumulation of $461.04 \mathrm{mg}$

Table 1 - Rates of macronutrients $\left(\mathrm{g} \mathrm{kg}^{-1}\right)$ in Solanum americanum plants grown under standard nutrient conditions. FCAV/UNESP, Brazil, 2007

\begin{tabular}{|r|c|c|c|c|c|c|}
\hline DAE & $\mathbf{N}$ & $\mathbf{P}$ & $\mathbf{K}$ & $\mathbf{C a}$ & $\mathbf{M g}$ & $\mathbf{S}$ \\
\hline 21 & 37.31 & 3.85 & 53.08 & 17.69 & 5.38 & 1.90 \\
\hline 35 & 31.94 & 3.30 & 47.31 & 19.69 & 5.90 & 1.76 \\
\hline 49 & 34.44 & 3.43 & 38.80 & 27.24 & 5.15 & 1.73 \\
\hline 63 & 33.58 & 3.14 & 37.58 & 23.22 & 5.87 & 1.96 \\
\hline 77 & 33.65 & 3.58 & 39.82 & 23.22 & 5.45 & 2.00 \\
\hline 91 & 30.67 & 2.49 & 38.27 & 19.29 & 6.35 & 2.47 \\
\hline 105 & 28.32 & 2.33 & 35.76 & 19.78 & 5.94 & 2.44 \\
\hline 119 & 27.95 & 2.04 & 32.71 & 21.57 & 5.62 & 2.43 \\
\hline 133 & 27.47 & 2.12 & 29.53 & 20.91 & 5.87 & 2.39 \\
\hline 147 & 26.86 & 2.54 & 28.09 & 17.09 & 5.79 & 2.82 \\
\hline 161 & 25.98 & 2.58 & 30.56 & 18.58 & 5.48 & 2.49 \\
\hline
\end{tabular}

DAE - Days after emergence. 

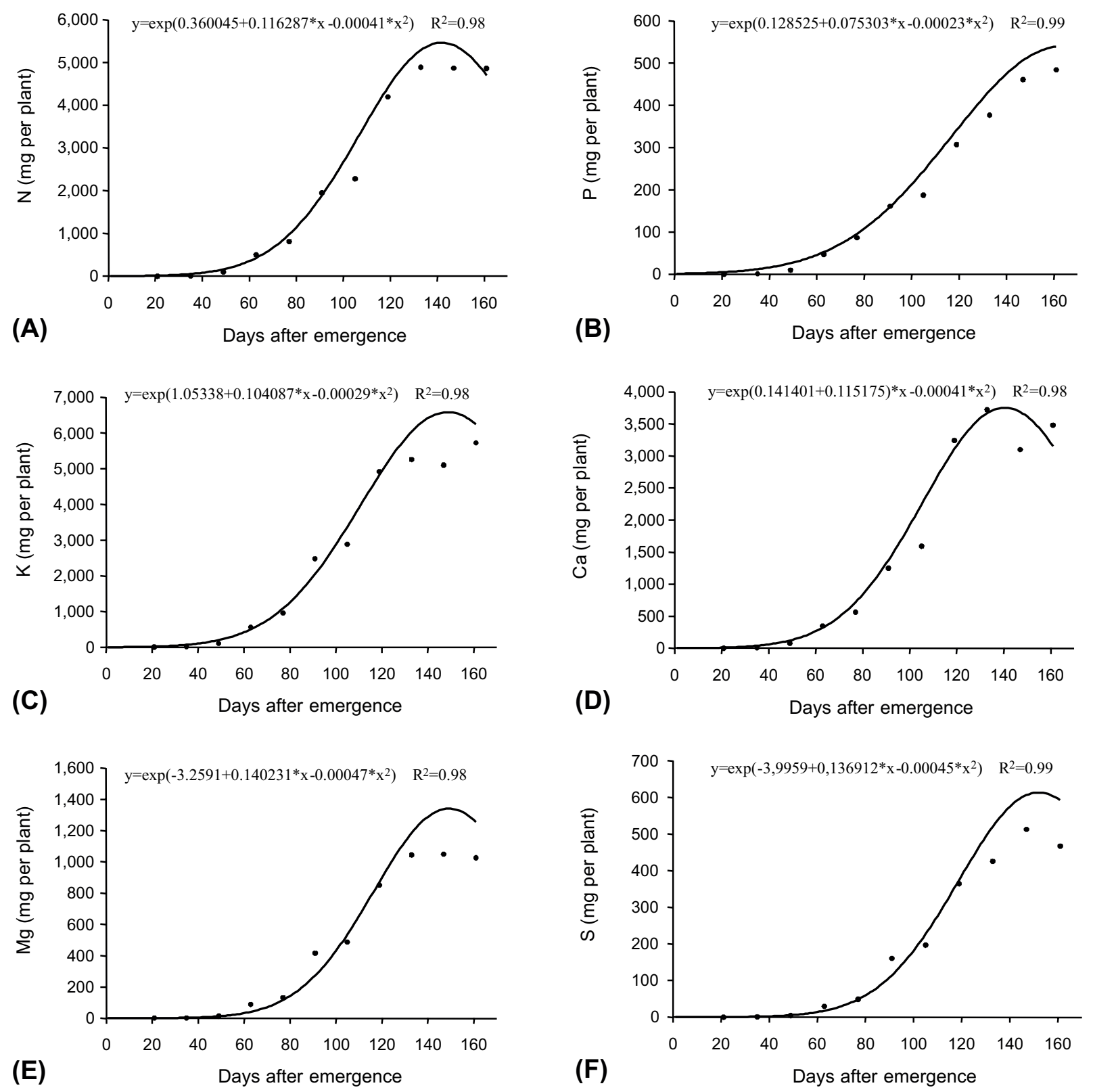

Figure 2 - Regression of the mean data of accumulation of nitrogen (A), phosphorus (B), potassium (C), calcium (D), magnesium (E), and sulfur (F) in Solanum americanum plants grown under standard nutrient conditions.

of $P$ per plant at $147 \mathrm{DAE}$, while $3,239.26 \mathrm{mg}$ of Ca were accumulated per plant at $119 \mathrm{DAE}$ and $425.32 \mathrm{mg}$ of $\mathrm{S}$ were accumulated per plant at 133 DAE.

Comparing the results of this research with those obtained on broadleaved weeds, it may be evidenced that, in the PMtAM, $S$. americanum accumulated more $\mathrm{N}, \mathrm{P}, \mathrm{K}, \mathrm{Ca}$, $\mathrm{Mg}$ and $\mathrm{S}$ than $\mathrm{D}$. tortuosum (Bianco et al., 2004b), E. heterophylla (Bianco et al., 2007), I. nil (Duarte et al., 2008) and I. quamoclit (Carvalho et al., 2009), R. brasiliensis (Pedrinho Júnior et al., 2004) and S. obtusifolia (Bianco et al., 2008). Therefore, S. americanum was more demanding for macronutrients than these weeds.

The macronutrients that accumulated the most in S. americanum plants were those 
displaying the highest rates. $\mathrm{K}$ accumulated more than $\mathrm{N}$. The uptake sequence was $\mathrm{K}>\mathrm{N}$ $>\mathrm{Ca}>\mathrm{Mg}>\mathrm{P}>\mathrm{S}$. Bianco et al. (2004b), Pedrinho Júnior et al. (2004), Bianco et al. (2007), Bianco et al. (2008), Duarte et al. (2008) and Carvalho et al. (2009) observed that $\mathrm{N}$ and $\mathrm{K}$ accumulated the most in the broadleaved weeds already studied. $\mathrm{N}$ and $\mathrm{K}$ are also known as the most demanded nutrients for most crops of economic interest (Epstein \& Bloom, 2005). Thus, competition of $S$. americanum plants for macronutrients is an important biotic factor affecting negatively the crops growth, development and productivity.

Bianco et al. (2004a,b) and Bianco et al. (2007) reported that the period for the greatest competition for nutrients among weeds and most annual crops in Brazil is around $77 \mathrm{DAE}$; as a result of uptake intensification, which was also observed in this study. During this period, just one $S$. americanum plant accumulated $24.07 \mathrm{~g}$ of dry matter, $810.02 \mathrm{mg}$ of $\mathrm{N}, 160.21 \mathrm{mg}$ of P, $958.54 \mathrm{mg}$ of $\mathrm{K}, 558.98 \mathrm{mg}$ of $\mathrm{Ca}, 131.30 \mathrm{mg}$ of $\mathrm{Mg}$ and $51.72 \mathrm{mg}$ of S. Comparing these results with those already verified on broadleaved weeds, it may be stated that $S$. americanum is more competitive for macronutrients than D. tortuosum, E. heterophylla, I. nil, I. quamoclit, R. brasiliensis and S. obtusifolia at $77 \mathrm{DAE}$, growing under standard nutrient conditions.

Therefore: (i) leaves and stems are the main structures accumulating dry matter in the first and second half of the $S$. americanum life cycle, respectively; (ii) $\mathrm{N}$ and $\mathrm{K}$ are the macronutrients most accumulated by $S$. americanum plants; and (iii) theoretical period of maximum dry matter and macronutrient accumulation for S. americanum was between 140 and 164 DAE.

\section{LITERATURE CITED}

ADKINS, J. et al. Critical period of interference between Amerimay black nightshade and seedless watermelon. Hort Sci., v. 43, n. 4, p. 1139-1140, 2008.

ANDREASEN, C.; LITZ, A. S.; STREIBIG, J. C. Growth response of six weed species and spring barley (Hordeum vulgare) to increasing levels of nitrogen and phosphorus. Weed Technol., v. 46, n. 6, p. 503-512, 2006.

BIANCO, S.; BARBOSA JÚNIOR, A. F.; PITELLI, R. A. Crescimento e nutrição mineral de capim-camalote. Planta Daninha, v. 22, n. 3, p. 375-380, 2004a.

Planta Daninha, Viçosa-MG, v. 28, n. 2, p. 293-299, 2010
BIANCO, S.; PITELLI, R. A.; BELLINGIERI, P. A. Crescimento e nutrição mineral de Desmodium tortuosum (Sw.) DC. Cult. Agron., v. 13, n. 2, p. 78-88, 2004 b.

BIANCO, S.; TONHÃO, M. A. R.; PITELLI, R. A. Crescimento e nutrição mineral de capim-braquiária. Planta Daninha, v. 23, n. 3, p. 423-428, 2005.

BIANCO, S.; PITELLI, R. A.; CARVALHO, L. B. Estudo comparativo do acúmulo de matéria seca e macronutrientes por plantas de Glycine max (L.) Merr. e Euphorbia heterophylla L. Ensayos Ci., v. 11, n. 2, p. 61-72, 2007.

BIANCO, S.; PITELLI, R. A.; CARVALHO, L. B. Crescimento e nutrição mineral de fedegoso. Ci. Cult., v. 3, n. 1, p. $35-41,2008$.

BLANCO, F. M. C. Manejo de plantas daninhas na cultura da batata. Biológico, v. 70, n. 1, p. 19-24, 2008.

BRIGHENTI, A. M.; VOLL, E.; GAZZIERO, D. L. P. Biologia e manejo do Cardiospermum halicacabum. Planta Daninha, v. 21, n. 2, p. 229-237, 2003.

CARVALHO, L. B. et al. Estudo comparativo do acúmulo de matéria seca e macronutrientes por plantas de milho var. BR-106 e Brachiaria plantaginea. Planta Daninha, v. 25, n. 2, p. 293-301, 2007.

CARVALHO, L. B. et al. Interferência e estudo fitossociológico da comunidade infestante em beterraba de semeadura direta. Planta Daninha, v. 26, n. 2, p. 291-299, 2008a.

CARVALHO, L. B. et al. Interferência e estudo fitossociológico da comunidade infestante na cultura da beterraba transplantada. Acta Sci. Agron., v. 30, n. 3, p. 325-331, 2008b.

CARVALHO, L. B.; BIANCO, S.; PITELLI, R. A. Growth and mineral nutrition of Ipomoea quamoclit.

Planta Daninha, v. 27, n. 2, p. 283-288, 2009.

CARVALHO, L. B.; GUZZO, C. D. Adensamento da beterraba no manejo de plantas daninhas. Planta Daninha, v. 26, n. 1, p. $73-82,2008$.

CORRÊA, J. C.; SHARMA, R. D. Produtividade do algodoeiro herbáceo em plantio direto no Cerrado com rotação de culturas. Pesq. Agropec. Bras., v. 39, n. 1, p. 41-46, 2004.

DIAS, T. C. S. et al. Efeito do espaçamento entre fileiras de amendoim rasteiro na interferência de plantas daninhas na cultura. Planta Daninha, v. 27, n. 2, p. 221-228, 2009.

DUARTE, D. J. et al. Crescimento e nutrição mineral de Ipomoea nil. Planta Daninha, v. 26, n. 3, p. 577-583, 2008. 
EPSTEIN, E.; BLOOM, A. J. Mineral nutrition of plants: principles and perspectives. 2.ed. Matterachussets: Sinauer, 2005. $380 \mathrm{p}$.

ERASMO, E. A. L. et al. Efeito de níveis crescentes de calagem no crescimento e estado nutricional de fedegoso. Planta Daninha, v. 18, n. 2, p. 253-263, 2000.

GILBERT, C. A. et al. Season-long interference of Amerimay black nightshade with watermelon. Weed Technol., v. 22, n. 1, p. 186-189, 2008.

GRAVENA, R. et al. Análise do crescimento de Hyptis suaveolens. Planta Daninha, v. 20, n. 2, p. 189-196, 2002.

HERNANDEZ, D. D. et al. Períodos de interferência de maria-pretinha sobre tomateiro industrial. Hortic. Bras. v. 25, n. 2, p. 199-204, 2007.

HOAGLAND, D. R.; ARNON, D. J. The water culture method of growing plants without soil. Berkeley: University of California, 1950. 31 p. (Circular, 347).

JORGENSEN, S. S. Metodologia utilizada para análises químicas de rotina: guia analítico. Piracicaba: CENA, 1977. $24 \mathrm{p}$.

KAZDA, M. et al. Importance of mineral nutrition for photosynthesis and growth of Quercus petraea, Fagus sylvatica and Acer pseudoplatanus planted under Norway spruce mayopy. Plant Soil, v. 264, n. 1-2, p. 25-34, 2004

KISSMANN, K. G.; GROTH, D. Plantas infestantes e nocivas. 2.ed. São Paulo: BASF, 1999. Tomo II. 978 p.

KUVA, M. A. et al. Fitossociologia de comunidades de plantas daninhas em agroecossistema cane-crua. Planta Daninha, v. 25, n. 3, p. 501-511, 2007.

LORENZI, H. Plantas daninhas do Brasil: terrestres, aquáticas, parasitas e tóxicas. 3.ed. Nova Odessa: Instituto Plantarum, 2000. $608 \mathrm{p}$.

MANOKO, M. L. K. et al. AFLP markers support separation of Solanum nodiflorum from

Solanum americanum sensu stricto (Solanaceae). Plant Syst. Evol., v. 267, n. 1, p. 1-11, 2007.

MONQUERO, P. A. et al. Mapas de infestação de plantas daninhas em diferentes sistemas de colheita da cana-de-açúcar. Planta Daninha, v. 26, n. 1, p. 47-55, 2008.
NASCENTE, A. S. et al. Interferência das plantas daninhas na cultura do tomate para processamento. Hortic. Bras., v 22, n. 3, p. 602-606, 2004.

NEPOMUCENO, M. P. et al. Efeito da época de semeadura nas relações de interferência entre uma comunidade infestante e a cultura do amendoim. Planta Daninha, v. 25, n. 3, p. $481-488,2007 \mathrm{a}$

NEPOMUCENO, M. et al. Períodos de interferência das plantas daninhas na cultura da soja nos sistemas de semeadura direta e convencional. Planta Daninha, v. 25, n. 1, p. 43-50, 2007b.

OLYKAN, S. T. et al. Effect of boron fertiliser, weed control and genotype on foliar nutrients and tree growth of juvenile Pinus radiata at two contrasting sites in New Zealand. For. Ecol. Manag., v. 255, n 3-4, p. 1196-1209, 2008.

PEDRINHO JÚNIOR, A. A. F.; BIANCO, S.; PITELLI, R. A. Acúmulo de matéria seca e macronutrientes por plantas de Glycine max e Richardia brasiliensis. Planta Daninha, v. 22, n. 1, p. 53-61, 2004

PITELLI, R. A.; PAVANI, M. C. M. D. Feralidade e trangienese. In: BOREM, A. (Org.). Biotecnologia e meio ambiente. Viçosa, MG: Universidade Federal de Viçosa, 2004. p. 263-278.

RONCHI, C. P. et al. Manejo de plantas daninhas na cultura do mamoeiro. Planta Daninha, v. 26, n. 4, p. 937-947, 2008.

SARRUGE, J. R.; HAAG, H. P. Análises químicas em plantas. Piracicaba: ESALQ/USP, 1974. 56 p.

SOARES, D. J. et al. Períodos de interferência das plantas daninhas na cultura de cebola (Allium cepa) transplantada. Planta Daninha, v. 21, n. 3, p. 387-396, 2003.

SOARES, D. J. et al. Efeito de diferentes períodos de controle das plantas daninhas na produtividade da cultura da cebola. Planta Daninha, v. 22, n. 4, p. 517-527, 2004.

SOUZA FILHO, A. P. S.; VELOSO, C. A. C.; GAMA, J. R N. Capacidade de absorção de nutrientes do capim-marandu (Brachiaria brizantha) e da planta daninha malva (Urena lobata) em função do pH. Planta Daninha, v. 18, n. 3 , p. 443-450, 2000.

TAIZ, L.; ZIEGER, E. Plant physiology. 3.ed. Sunderland: Sinauer, 2002. 690 p.

VITTI, G. C. Avaliação e interpretação do enxofre no solo e na planta. Jaboticabal: FUNEP, 1989. 37 p. 